BBA 37122

\title{
STUDIES ON THE RECONSTITUTION OF BOVINE ERYTHROCYTE SUPER- OXIDE DISMUTASE
}

\section{PREPARATION AND PROPERTIES OF DERIVATIVES IN WHICH BOTH ZINC AND COPPER SITES CONTAIN COPPER}

JAMES A. FEE ${ }^{\star}$ and R. G. BRIGGS ${ }^{\star \star}$

Department of Chemistry, Rensselaer Polytechnic Institute, Troy, N.Y. 12181 (U.S.A.) and Biophysics Research Division, Instirute of Science and Technology, University of Michigan, Ann Arbor, Mich. 48105 (U.S.A.)

(Received February 18th, 1975)

\section{SUMMARY}

1. We have developed a procedure for preparing derivatives of bovine superoxide dismutase in which primarily the $\mathrm{Cu}$ binding sites are occupied by $\mathrm{Cu}^{2+}$ $\left(2 \mathrm{Cu}^{2+}\right)$ and in which both the $\mathrm{Zn}$ and $\mathrm{Cu}$ binding sites are occupied by $\mathrm{Cu}^{2+}$ $\left(4 \mathrm{Cu}^{2+}\right)$.

2. The $2 \mathrm{Cu}^{2+}$ protein shows approximately one-half the superoxide dismutase activity of an equivalent amount of native protein. A two-fold enhancement of the activity of $2 \mathrm{Cu}^{2+}$-dismutase was observed upon occupation of the $\mathrm{Zn}$ sites either with $\mathrm{Zn}^{2+}$ or $\mathrm{Cu}^{2+}$.

3. The electron paramagnetic resonance spectrum of $4 \mathrm{Cu}^{2+}$ protein was recorded over the temperature range $5-100^{\circ} \mathrm{K}$ and the results suggest an antiferromagnetic interaction between $\mathrm{Cu}^{2+}$ in the $\mathrm{Zn}$ site and $\mathrm{Cu}^{2+}$ in the $\mathrm{Cu}$ site having a coupling constant of approx. $52 \mathrm{~cm}^{-1}$.

4. The binuclear $\mathrm{Cu}^{2+}$ complex was found to accept only one electron from ferrocyanide.

5. One-half the total $\mathrm{Cu}^{+}$of dithionite reduced $4 \mathrm{Cu}^{+}$protein was found to react rapidly with bathocupreine sulfonate whereas the other half reacted slowly. Reduced native protein did not react with bathocupreine sulfonate below $70^{\circ} \mathrm{C}$.

\section{INTRODUCTION}

Superoxide dismutase from bovine erythrocytes has recently been the subject \footnotetext{
acetic acid.

Abbreviations used: EPR, electron paramagnetic resonance; EDTA, ethylenediaminetetra-

* Address all inquiries to this author. Present address: Biophysics Research Division, Institute of Science and Technology, University of Michigan, Ann Arbor, Mich. 48105 (U.S.A.).

** Present address: Department of Chemistry, State University of New York, Albany, N.Y. (U.S.A.).
} 
of intensive investigation utilizing a number of different experimental methods. These results have allowed a number of predictions to be made regarding the general structural features of the active site region. Copper which is essential for dismutase activity [1] has been shown to undergo a cycle of reduction and oxidation during catalysis $[2,3]$. It has been shown that at least one rapidly exchanging water molecule [4] is bound to the $\mathrm{Cu}^{2+}$ which is further coordinated by at least three nitrogenous ligands [5-7] proposed to be imidazole groups [8]. At least one ligand to the $\mathrm{Cu}^{2+}$ must be a very strong Bronsted base with a $\mathrm{p} K_{\mathrm{a}}>9$ [9]. The $\mathrm{Zn}^{2+}$ [10] ion was proposed to be in close proximity to the $\mathrm{Cu}^{2+}$ [5], and sound supportive evidence came from studies of the EPR properties of dismutase in which $\mathrm{Zn}^{2+}$ was replaced by a paramagnetic metal ion: $\mathrm{Cu}^{2+}[7]$ and $\mathrm{Co}^{2+}[11,12]$.

The early work [7] in which $\mathrm{Zn}^{2+}$ was replaced by $\mathrm{Cu}^{2+}$ demonstrated a magnetic interaction between two $\mathrm{Cu}^{2+}$ ions which were considered to be some $0.5-0.6 \mathrm{~nm}$ apart, but the nature of the magnetic interaction was not understood and it was not possible then to reproducibly prepare samples of what is referred to as $4 \mathrm{Cu}^{2+}$ dismutase in this communication. Similarly, in the case of $\mathrm{Co}^{2+}$ substitution $[11,12]$ a magnetic interaction was demonstrated but its nature was not known.

It is the purpose of this paper to describe the preparation of $4 \mathrm{Cu}^{2+}$ dismutase and some of the spectroscopic, magnetic, and chemical properties of the bound copper. Our results on the magnetic properties of the $2 \mathrm{Co}^{2+} 2 \mathrm{Cu}^{2+}$ derivative will be reported later [13]; these offer further evidence for a close proximity and a strong interactive dependence between the $\mathrm{Zn}$ and $\mathrm{Cu}$ binding sites.

The general predictions and deductions about the active center region made from physical and chemical experiments have been generally confirmed and put in detailed perspective with the recent determination of the structure of bovine superoxide dismutase at a resolution of $0.3 \mathrm{~nm}$ by the Richardsons [14]. Briefly, the active site region consists of a $\mathrm{Cu}^{2+}$ surrounded by a roughly square array of imidazole moieties, one of which also serves as a bridging ligand to the $\mathrm{Zn}^{2+}$. The electron density maps indicate that one coordination position above the plane of the paper in Scheme I and toward the solvent is not occupied by a ligand from the protein. The position of the $\mathrm{H}_{2} \mathrm{O}$ in Scheme I is inferred from the NMR studies [4], and this may

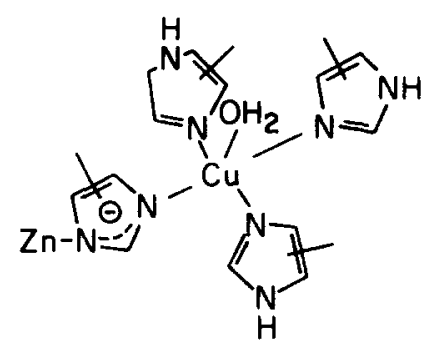

be the site at which catalysis of superoxide dismutation occurs. The $\mathrm{Zn}^{2+}$ ion is coordinated to three additional ligands in a roughly tetrahedral arrangement. Most previous work can be interpreted in terms of this structure. 


\section{MATERIALS AND METHODS}

Superoxide dismutase was obtained from bovine erythrocytes and assayed as described by McCord and Fridovich [1], and apoprotein was prepared as previously described [11]. Bathocupreine sulfonate was obtained from G. F. Smith Chemical Co. All other reagents were of highest commercial quality and glass distilled water was used throughout.

Copper analyses were performed by standard atomic absorption techniques after precipitation of protein by trichloroacetic acid or by a colorimetric procedure utilizing bathocupreine sulfonate [15].

Optical absorption spectra were recorded on Cary Model 14, Coleman 124 Perkin-Elmer, or Cary 118 spectrophotometers. EPR spectra were obtained using either a Varian E-9 or a V-4502 Model. Sample temperatures to $100^{\circ} \mathrm{K}$ were obtained with the device described by Hansen et al. [16] while below $100^{\circ} \mathrm{K}$ an Air Products Helitran ${ }^{\circledR}$ System was used with liquid helium as refrigerant. Procedures were generally as described in previous communications in this series [11].

\section{RESULTS}

\section{Preparation of $4 \mathrm{Cu}^{2+}$ dismutase}

Freshly prepared apoprotein was slowly titrated with $\mathrm{Cu}^{2+}$ as described in the legend to Fig. 1, and at each point indicated the delivery was stopped and an EPR spectrum of an aliquot of the reaction mixture was recorded. At the same time $3.5 \mu \mathrm{l}$ of the reaction mixture was diluted into $1.0 \mathrm{ml}$ acetate buffer, $I=0.1, \mathrm{pH}=5.5$, for assay of superoxide dismutase activity. The development of activity, relative to an equal concentration of native protein, is shown in Fig. 2A.

During the early stages of the titration the EPR spectrum was characteristic of an isolated cupric ion, but when more than two equivalents of $\mathrm{Cu}^{2+}$ were added an attenuation of signal height became evident and eventually a very broad, featureless spectrum resulted showing no hyperfine structure. Concomitant with the appearance of this broad spectrum was the appearance of a new, weaker signal in the $1400-1500 \mathrm{G}$ region. This signal, like the broad signal at higher field exhibited no structure when recording conditions designed to give greater amplification and resolution were used [7]. The structure apparent in the high-field signal, centered around $3200 \mathrm{G}$ is due to a very small amount of non-specifically bound ${ }^{\star} \mathrm{Cu}^{2+}$. The full spectrum, shown in Fig. 3, can be reproducibly obtained by the above procedure and is identical with that published previously [7]. This unusual EPR spectrum characteristically arises from two $\mathrm{Cu}^{2+}$ ions in close proximity to one another [17] and in line with our previous deductions regarding the proximity of the $\mathrm{Zn}^{2+}$ and $\mathrm{Cu}^{2+}$ binding sites $[7,11]$, we consider $4 \mathrm{Cu}^{2+}$ dismutase to contain $\mathrm{Cu}^{2+}$ in both metal binding sites.

The development of superoxide dismutase activity was measured in the presence and absence of EDTA (Fig. 2A). It can be seen that in the absence of EDTA the activity increases in proportion with added $\mathrm{Cu}^{2+}$ while in the presence of $0.1 \mathrm{mM}$ EDTA in the assay mixture approximately the first $2 \mathrm{Cu}^{2+}$ added show relatively

* In these experiments it was observed that freshly prepared, highly purified, apoprotein was required to prevent the premature onset of non-specific $\mathrm{Cu}^{2+}$ binding. 


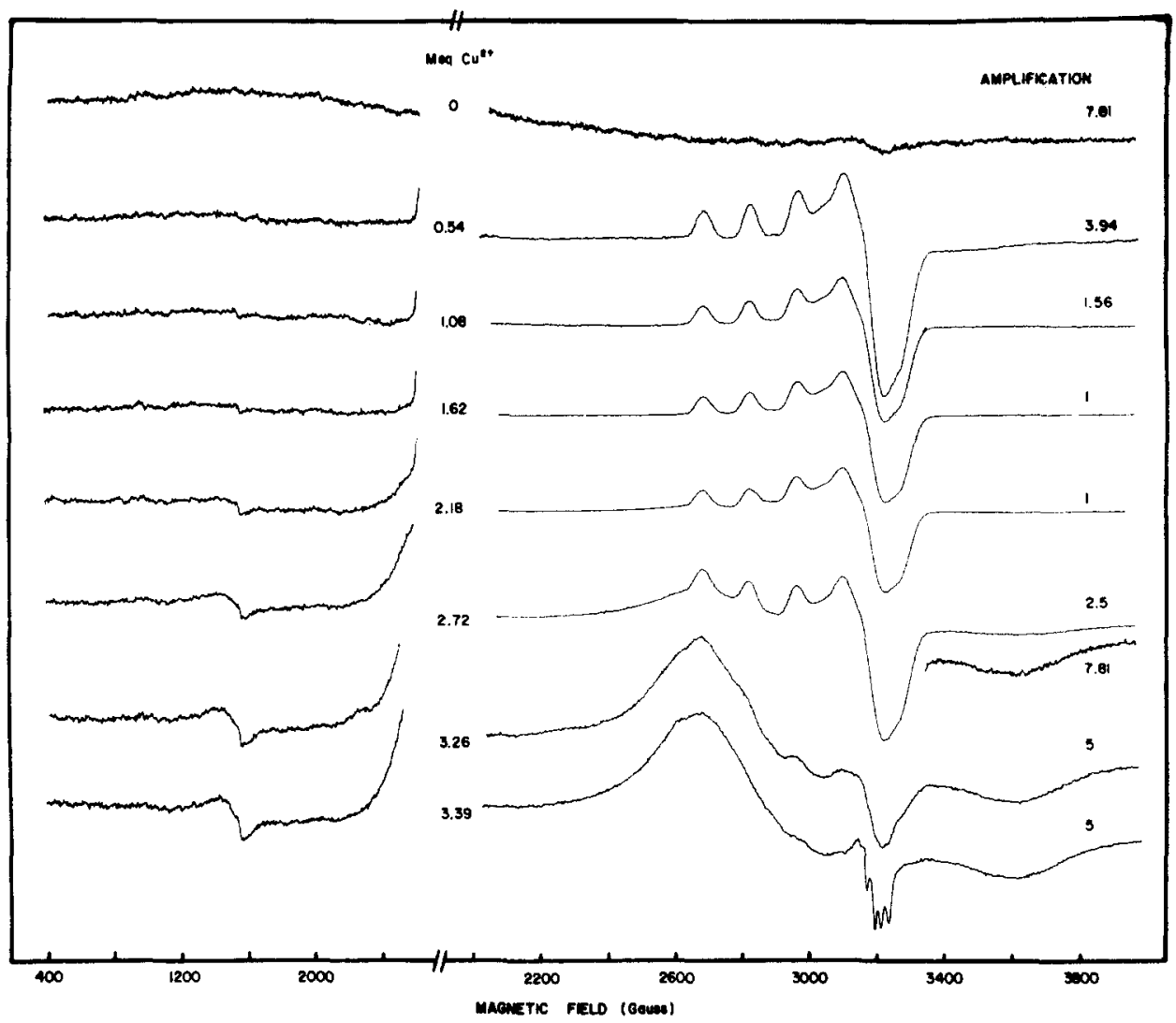

Fig. 1. EPR titration of apo superoxide dismutase with cupric ions. The experiment was carried out by slowly infusing $15.8 \mathrm{mM}^{63} \mathrm{CuCl}_{2}$ into $2.0 \mathrm{ml}$ of $0.29 \mathrm{mM}$ apoprotein buffered at $\mathrm{pH} 5.5$ with $J=$ 0.25 sodium acetate buffer. This solution was stirred with a small magnet stirring bar during the experiment. The infusion rate of the $\mathrm{CuCl}_{2}$ solution was $3.47 \cdot 10^{-4} \mathrm{ml} / \mathrm{min}$. The addition of $\mathrm{Cu}^{2+}$ was stopped at various times and an aliquot taken for EPR analysis which was subsequently returned to the reaction vessel before continuing the experiment. At these times $3.46 \mu \mathrm{l}$ of the solution was diluted into $1-\mathrm{ml}$ portions of acetate buffer, $I=0.5$, pH 5.5 and stored on ice for later determination of superoxide dismutase activity (cf. Fig. 2). The EPR spectra were recorded near $100{ }^{\circ} \mathrm{K}$ with 100 $\mathrm{kHz}$ field modulation at an amplitude of $10 \mathrm{G}$. The microwave power was $50 \mathrm{~mW}$ at a frequency of $9.233 \mathrm{GHz}$ as measured by a Hewlett Packard Model X532B frequency meter. The relative amplification factors are given in the figure, and the low field portion was always recorded at a relative gain of 7.81 .

little activity while the second two $\mathrm{Cu}^{2+}$ give a rapid increase in activity. The differences lie considerably outside the average deviations indicated by the error bars. In other experiments, it was shown that even very high concentrations of EDTA have no effect on the EPR spectrum of either $2 \mathrm{Cu}$ of $4 \mathrm{Cu}$ dismutase. Thus, the apparent inhibition of the dismutase activity by EDTA does not involve its binding to the oxidized form of these proteins.

The optical absorption spectrum of $4 \mathrm{Cu}^{2+}$ dismutase is shown in Fig. 4 where it is compared with that of the $2 \mathrm{Cu}^{2+}$ derivative. Other properties of $4 \mathrm{Cu}$ dismutase will be presented in comparison with native and $2 \mathrm{Cu}$ proteins. 


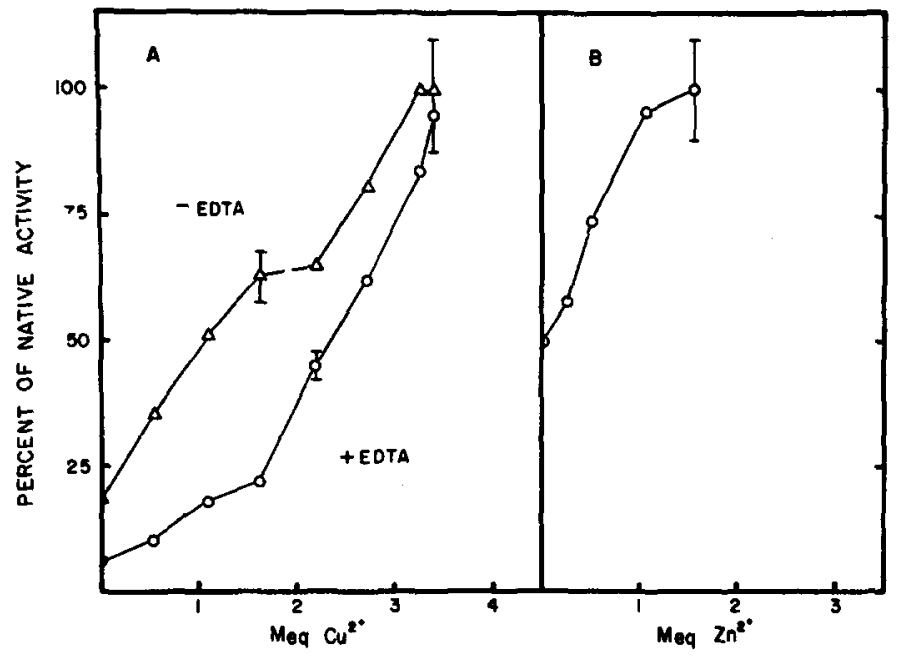

Fig. 2. Activity titration of apo superoxide dismutase with $\mathrm{Cu}^{2+}(\mathrm{A})$ and $2 \mathrm{Cu}^{2+}$ superoxide dismutase with $\mathrm{Zn}^{2+}(\mathrm{B})$. All measurements made relative to an equal amount of native protein, not to native $\mathrm{Cu}^{2+}$ concentration (see text for details).

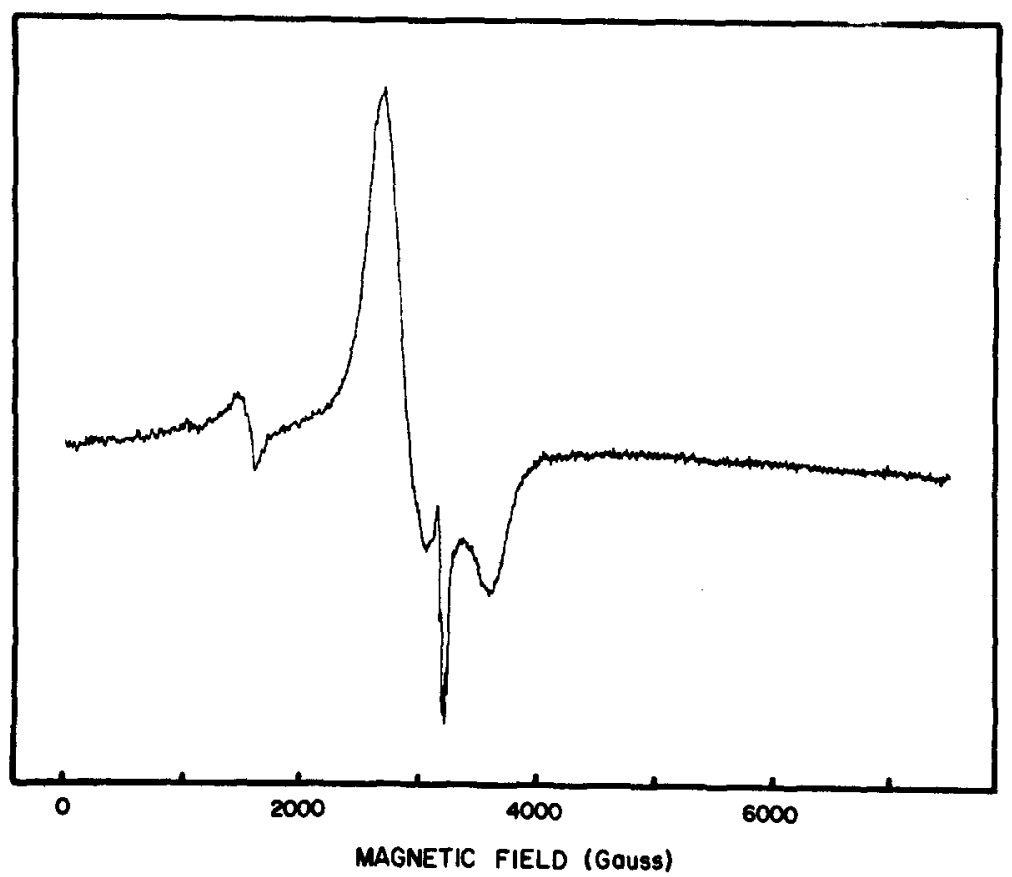

Fig. 3. The EPR spectrum of $4 \mathrm{Cu}^{2+}$ superoxide dismutase. The spectrum was recorded at $100{ }^{\circ} \mathrm{K}$, $10 \mathrm{G}$ modulation amplitude, $100 \mathrm{~mW}$ of mictowave power, the time constant was $0.1 \mathrm{~s}$, and the sweep rate was $1000 \mathrm{G} / \mathrm{min}$. 


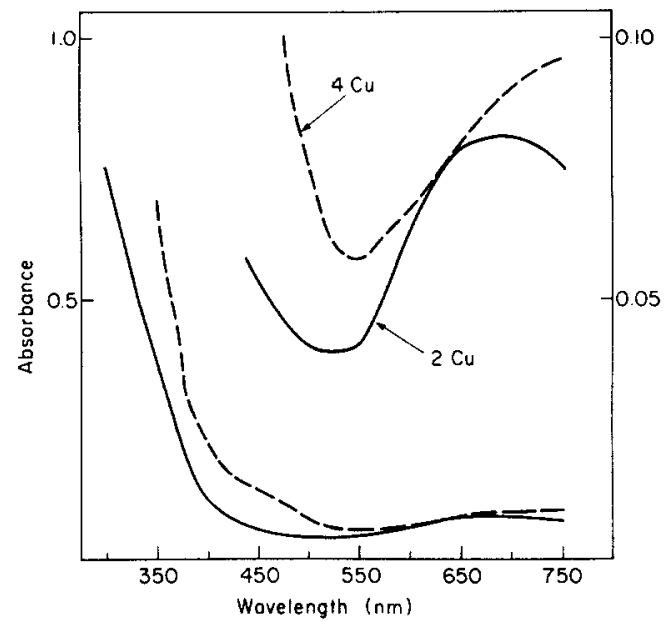

Fig. 4. Visible optical spectra of $2 \mathrm{Cu}^{2+}$ and $4 \mathrm{Cu}^{2+}$ derivatives of superoxide dismutase. The $2 \mathrm{Cu}$ sample was $0.34 \mathrm{mM}$ in protein and $0.65 \mathrm{mM}$ in $\mathrm{Cu}^{2+}$ (see text); and the $4 \mathrm{Cu}$ sample was $0.27 \mathrm{mM}$ in protein and $0.93 \mathrm{mM}$ in $\mathrm{Cu}^{2+}$. Both solutions were $0.25 \mathrm{M}$ acetate buffer, $\mathrm{pH}$ 5.5. The optical spectrum of the $2 \mathrm{Cu}$ solution was recorded after clarification by centrifugation, and that of $4 \mathrm{Cu}$ after passage through a $0.45 \mu \mathrm{m}$ Millipore filter. In spite of these precautions there may be a small contribution from light scattering to the observed optical density, particularly below $400 \mathrm{~nm}$.

\section{Preparation of $2 \mathrm{Cu}$ superoxide dismutase}

The $2 \mathrm{Cu}^{2+}$ dismutase can be prepared essentially the same as the $4 \mathrm{Cu}^{2+}$ derivative except that fewer equivalents of $\mathrm{Cu}^{2+}$ are added. In one such experiment $1.73 \mu \mathrm{mol} \mathrm{Cu}{ }^{2+}$ were added slowly to $0.96 \mu \mathrm{mol}$ apoprotein to a final concentration of $0.34 \mathrm{mM}$ protein and $0.65 \mathrm{mM} \mathrm{Cu}^{2+}$. The EPR spectrum of this solution showed predominantly the $2 \mathrm{Cu}^{2+}$ spectrum evident in Fig. 1, but it was superimposed on a broader spectrum of low intensity which was characteristic of $4 \mathrm{Cu}$ derivative, indicating that the second binding site has an affinity for $\mathrm{Cu}^{2+}$ which is less than, but comparable with that of the first binding site. The optical absorption spectrum of this sample is shown in Fig. 4.

The above $2 \mathrm{Cu}^{2+}$ protein sample was titrated with $\mathrm{Zn}^{2+}$ and the EPR spectrum was recorded. After the addition of an aliquot of $\mathrm{Zn}^{2+}$ the solution was allowed to incubate at $40{ }^{\circ} \mathrm{C}$ for $10 \mathrm{~min}$. Longer periods of time gave no further changes in the observed properties of the system. The added $\mathrm{Zn}^{2+}$ caused the appearance of some non-specifically bound $\mathrm{Cu}^{2+}$ and the disappearance of the broad underlying EPR spectrum. Most importantly, the added $\mathrm{Zn}^{2+}$ changed the qualitative features of the EPR spectrum from those of $2 \mathrm{Cu}^{2+}$ protein to those of native protein; $A_{\|}$ decreased from 140-150 to approx. $130 \mathrm{G}$. The non-specifically bound $\mathrm{Cu}^{2+}$ was readily removed by a brief treatment with Chelex to reveal an EPR spectrum identical with that of native protein. Integration of the EPR signal before and after treatment with Chelex showed that only $20 \%$ of the total $\mathrm{Cu}^{2+}$ was present in a non-specifically bound form. Presumably this $\mathrm{Cu}^{2+}$ was bound in close proximity to another $\mathrm{Cu}^{2+}$ and was displaced by $\mathrm{Zn}^{2+}$.

As a part of the same experiment, activity measurements were made after each addition of $\mathrm{Zn}^{2+}$ both before and after treatment with Chelex. Samples not treated 
with Chelex showed a large variation in activity while after removal of non-specific $\mathrm{Cu}^{2+}$ the activity of a particular sample could be reproducibly obtained (Fig. 2B). This is apparently due to the high dismutase activity of non-specifically bound $\mathrm{Cu}^{2+}$ reported earlier [22]. It can be seen that $\mathrm{Zn}^{2+}$ increases the efficiency of the dismutase activity of the specifically bound $\mathrm{Cu}^{2+}$.

\section{Oxidation-reduction properties of $4 \mathrm{Cu}^{2+}$ dismutase}

When $4 \mathrm{Cu}^{2+}$ dismutase was treated with a small excess of ferrocyanide at pH 5.5, the EPR spectrum was altered from that shown in Fig. 3 to that shown in Fig. 5 where it is compared with $2 \mathrm{Cu}^{2+}$ protein. The integrated intensity of this unusual spectrum which arises from a magnetically isolated $\mathrm{Cu}^{2+}$ accounted for $60 \%$ of the total $\mathrm{Cu}$ present in the solution. Thus, approximately half the total $\mathrm{Cu}$ in the sample must have been reduced to $\mathrm{Cu}^{+}$resulting in the removal of the magnetic interaction apparent in the $4 \mathrm{Cu}^{2+}$ sample. The same result was obtained when $\mathrm{H}_{2} \mathrm{O}_{2}$ was used as the reductant [9]. At higher $\mathrm{pH}$ values, $>8$, there was a lesser tendency for reduction by ferrocyanide, suggesting that the apparent reduction potential of one of the $\mathrm{Cu}^{2+}$ ions had decreased, in analogy with the native protein [9].

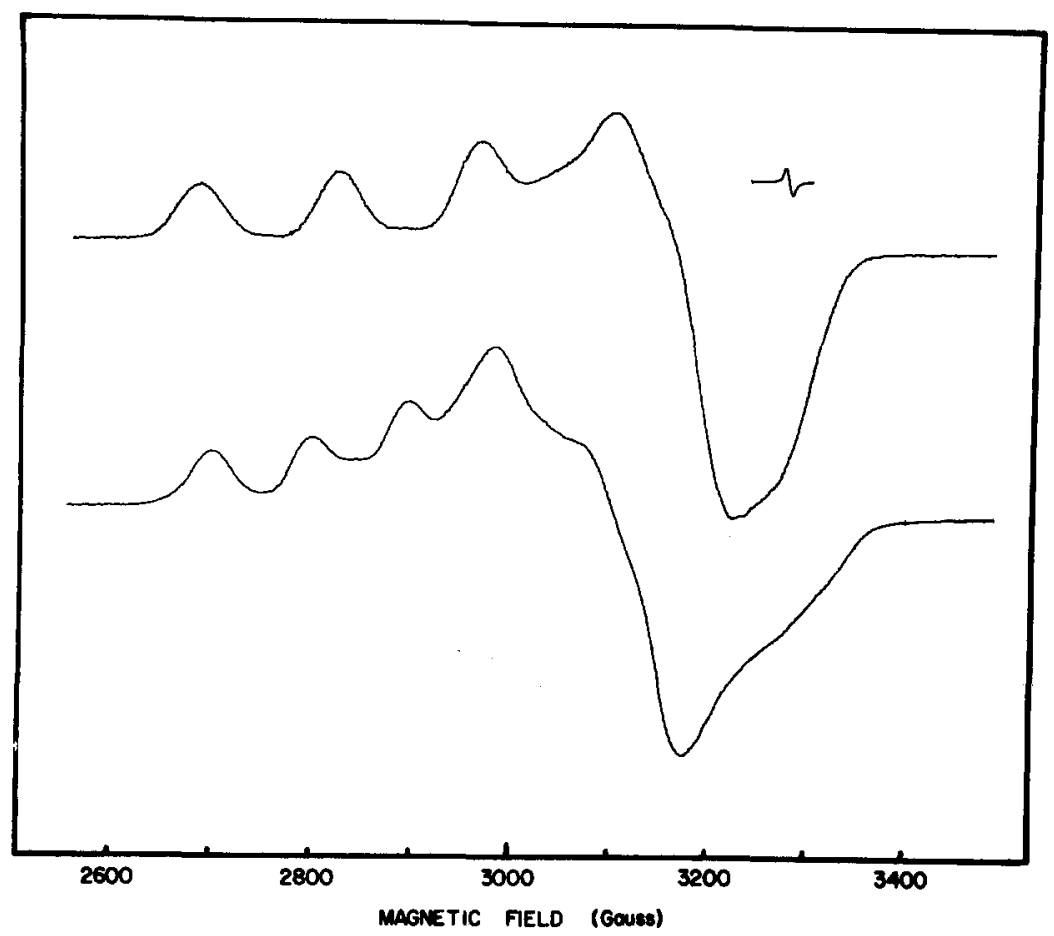

Fig. 5. The EPR spectra of $2 \mathrm{Cu}^{2+}$ and $2 \mathrm{Cu}^{+} 2 \mathrm{Cu}^{2+}$ superoxide dismutase derivatives. The conditions of recording are as in Fig. 1. The upper spectrum is also shown in Fig. 1 and arises from a sample containing $0.29 \mathrm{mM}$ apo dismutase and 1.08 mequiv ${ }^{63} \mathrm{Cu}^{2+}(2 \mathrm{Cu})$. The lower spectrum arises from a similar sample of apoprotein containing 3.39 mequiv $\mathrm{Cu}$ plus a small excess of potassium ferrocyanide. Spectral parameters are: $2 \mathrm{Cu}^{2+}$ derivative; $A_{||}=140, g_{\| \mid}=2.28$ and $g_{\mathrm{m}}=2.087$; $2 \mathrm{Cu} 2 \mathrm{Cu}^{2+}$ derivative, $A_{\| \mid}=100, g_{\| 1}=2.31$. 
Reactivity of protein bound $\mathrm{Cu}^{+}$in $2 \mathrm{Cu}^{+}$and $4 \mathrm{Cu}^{+}$derivatives

When the oxidized forms of these derivatives were treated with dithionite at pH 7.8 all $\mathrm{Cu}^{2+}$ was reduced to $\mathrm{Cu}^{+}$as indicated by EPR spectroscopy. It was found that bactocupreine sulfonate, a $\mathrm{Cu}^{+}$specific sequestering agent [15], would remove the $\mathrm{Cu}^{+}$from $4 \mathrm{Cu}^{+}$dismutase in two phases as evidenced by the formation of the chromophoric complex. As shown in Fig. 6 half the copper was rapidly complexed by this chelating agent, followed by slower reaction which plateaued near $75 \%$ reaction. Complete removal of this $\mathrm{Cu}^{+}$could be effected only by heating the solution to boiling. Notably, if allowed to stand at room temperature after heating there was a moderately slow decrease in $480 \mathrm{~nm}$ absorption indicating $\mathrm{Cu}^{+}$was being transferred from the bathocupreine sulfonate complex to a non-chromophoric site, presumably on the protein.

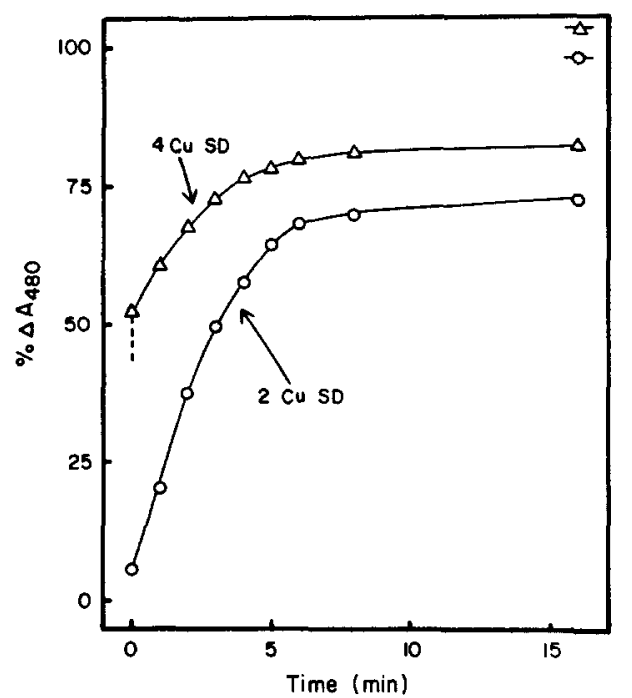

Fig. 6. Reactivity of fully reduced $4 \mathrm{Cu}$ and $2 \mathrm{Cu}$ derivatives of superoxide dismutase toward batho cupreine sulfonate. Solid sodium dithionite was added directly to an optical cuvette containing 1.8 $\mathrm{ml} 0.7 \mathrm{M}$ Tris $\cdot \mathrm{HCl}, \mathrm{pH} 7.4,0.2 \mathrm{ml} 1.53 \mathrm{mM}$ bathocupreine sulfonate, and $0.05 \mathrm{ml} 0.93 \mathrm{mM} \mathrm{Cu} \mathrm{Cu}^{2+}$ as $4 \mathrm{Cu}^{2+}$ superoxide dismutase or $0.1 \mathrm{ml} 0.46 \mathrm{mM} \mathrm{Cu}^{2+}$ as $2 \mathrm{Cu}^{2+}$ dismutase. The formation of the bathocupreine sulfonate- $\mathrm{Cu}^{+}$was observed at $480 \mathrm{~nm}$ for which an absorbance index of $1.25 \cdot 10^{4}$ $\mathrm{M}^{-1} \cdot \mathrm{cm}^{-1}$ was previously determined under these conditions. The $100 \%$ of the reaction was determined after vigorous boiling of the solution.

The reaction of $2 \mathrm{Cu}^{+}$protein with bathocupreine sulfonate did not show a rapid phase, and the rate was similar to the second, slower phase, of the reaction with $4 \mathrm{Cu}^{+}$protein. This suggests that the chelator reacts with $4 \mathrm{Cu}^{+}$protein to immediately form $2 \mathrm{Cu}^{+}$protein.

The behaviour of the reduced native protein was markedly different from either of these derivatives; bathocupreine sulfonate did not remove $\mathrm{Cu}^{+}$below $70{ }^{\circ} \mathrm{C}$ under the conditions used.

The temperature dependence of the EPR spectrum of $4 \mathrm{Cu}^{2+}$ dismutase

The EPR spectrum of the $4 \mathrm{Cu}^{2+}$ derivative was recorded over the temperature 
range: from approx. $5^{\circ} \mathrm{K}$ to greater than $100^{\circ} \mathrm{K}$. Below $10^{\circ} \mathrm{K}$ the EPR spectrum completely disappeared while above $10^{\circ} \mathrm{K}$ the intensity increased as shown in Fig. 7. There was no obvious change in the shape of the spectrum, and the intensity was taken by the height of the line near $2700 \mathrm{G}$ or the height of this line times the square of its linewidth which remained constant over the entire temperature range. The data shown in Fig. 7 were fitted by visual observation to a partition function involving an excited triplet state from which the EPR signal is obtained and a singlet ground state.

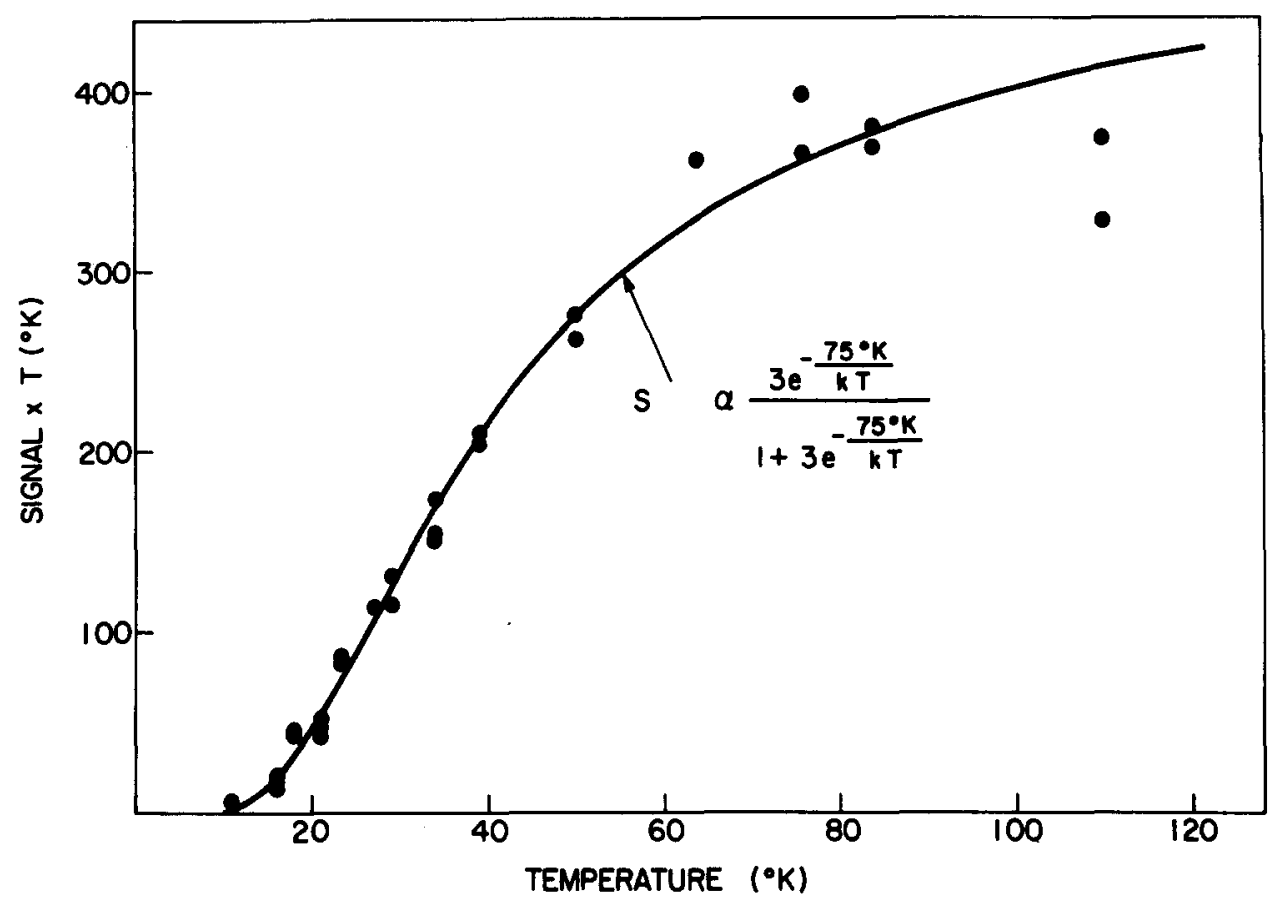

Fig. 7. Temperature dependence of the EPR signal of $4 \mathrm{Cu}^{2+}$ superoxide dismutase. The temperature of the sample was regulated with an Air Products Heli-tran ${ }^{\otimes}$ system, and signal intensity was determined from the height of the signal at $2694 \mathrm{G}$ in Fig. 2. The line is derived from a two-state partition function in which the degeneracy of the upper state is three-fold and that of the ground state is nondegenerate. The energy separation was estimated to be $75^{\circ} \mathrm{K}$.

\section{DISCUSSION}

The interpretation of the above results may be made in terms of the active site structure determined by the Richardsons' group [14] as roughly demonstrated in Scheme I. The results of the $\mathrm{Cu}^{2+}$ titration data shown in Fig. 1 are consistent with the presence of four metal binding sites on the protein and the observed magnetic properties suggest that $\mathrm{Cu}^{2+}$ ions are bound to the protein as binuclear clusters. The assumption that $\mathrm{Cu}^{2+}$ occupies the native $\mathrm{Zn}$ binding site requires the formation of a binuclear $\mathrm{Cu}^{2+}$ complex in which the imidazolium anion serves as the bridging ligand. While some evidence has indicated that in free aqueous medium imidazolato- 
bridged binuclear $\mathrm{Cu}^{2+}$ complexes are not formed even at an imidazole $/ \mathrm{Cu}^{2+}$ ratio greater than 4 [18] there is ample evidence for their existence in crystals which form from these aqueous solutions. Ivarsson et al. [19] have determined the structure of a trinuclear $\mathrm{Cu}^{2+}$ complex, (di- $\mu$-imidazolato-diperchlorato-octa-imidazolotricopper [11]) containing two imidazolato-bridging ligands, and Lundberg [20] has determined the structure of an imidazolato-bridged polynuclear (infinite chain) $\mathrm{Cu}^{2+}$ complex. In both of these structures each $\mathrm{Cu}^{2+}$ occupies a site of distorted octahedral symmetry, and the imidazolato-bridge occupies in-plane coordination positions on each of the $\mathrm{Cu}^{2+}$ ions. The above studies demonstrate that the imidazolium anion, which is quite a strong Bronsted Base [21, and references therein], can be stabilized by coordination between two $\mathrm{Cu}^{2+}$ ions and supports our conclusion that $\mathrm{Cu}^{2+}$ binds at the $\mathrm{Zn}^{2+}$ site.

It was previously reported $[22,23]$ that the rapid addition of $\mathrm{Cu}^{2+}$ ions to solutions of apoprotein resulted in superoxide dismutase activity arising from $\mathrm{Cu}^{2+}$ non-specifically associated with the protein. This was evidenced by a decrease in the fluorescence of the two tyrosine residues which are now known not to be part of the metal binding center [14], and the solution exhibited an EPR spectrum having a small linewidth unlike that of native enzyme. By contrast, the EPR spectra shown in Fig. 1 have the broad linewidth characteristic of specifically bound $\mathrm{Cu}^{2+}$. As was suggested previously [7] and is now known with certainty [24], the apoprotein has a somewhat different conformation than the native protein. In order for specific metal binding to occur at the active site the protein must regain the conformation of the holoprotein. This process appears to be slow ${ }^{\star}$ and is perhaps inhibited by nonspecifically bound $\mathrm{Cu}^{2+}$.

Clearly, there are two classes of metal binding sites one of which has a somewhat higher affinity for $\mathrm{Cu}^{2+}$ than the other. In several titrations similar to that presented in Fig. 1. occupation of the second or weaker affinity site occurred somewhat before the addition of 2 mequiv $\mathrm{Cu}^{2+}$. Thus, the affinity constants for the two sites do not differ greatly. It is reasonable to suggest that the higher affinity site be associated with the native $\mathrm{Cu}$ binding site, and the lower affinity site with the native $\mathrm{Zn}$ binding site.

If the tentative assignment of binding sites is correct then the results of the superoxide dismutase activity measurements have some relevance to the functional role of the $\mathrm{Zn}^{2+}$. The data shown in Fig. 2 suggest that occupation of the $\mathrm{Zn}$ site with either $\mathrm{Zn}^{2+}$ or $\mathrm{Cu}^{2+}$ increases the efficiency of catalysis by approx. $100 \%$. The small but apparent inhibition of the dismutase activity of $2 \mathrm{Cu}$ protein by EDTA in the assay medium also appears to be removed when the $\mathrm{Zn}$ site is occupied, but the lower activity of $2 \mathrm{Cu}$ protein may not be due entirely to EDTA inhibition as trace amounts of extraneous $\mathrm{Cu}^{2+}$ can contribute significantly to the apparent dismutase activity $[22,25,26]$. The data in Fig. 2 show that either approximately half the $\mathrm{Cu}$ of $4 \mathrm{Cu}^{2+}$ dismutase is inactive and the other is fully active or all the bound $\mathrm{Cu}$ has an average activity equal to half that of the native protein. The latter seems rather unlikely, and it is proposed that $\mathrm{Cu}^{2+}$ bound in the $\mathrm{Zn}^{2+}$ site does not have significant dismutase activity.

* Fridovich [27] has suggested that protein bound EDTA gave rise to the "anomalous binding of $\mathrm{Cu}^{2+}$ at sites other than the active site" reported previously in this series $[7,22,23]$. As discussed elsewhere [11], however, even in the complete absence of EDTA non-specific binding occurs on rapid addition of stoichiometric quantities of $\mathrm{Cu}^{2+}$ to apoprotein. 
One effect of the occupation of the $\mathrm{Zn}^{2+}$ binding site with $\mathrm{Cu}^{2+}$ or $\mathrm{Zn}^{2+}$ on the visible absorption spectrum is to induce the absorption band apparent as a pronounced shoulder near $450 \mathrm{~nm}$. Thus, the absorption spectrum of native protein is characterized by a broad envelope centered at $680 \mathrm{~nm}$ and a distinct shoulder at $450 \mathrm{~nm}$ [11] but as can be seen in Fig. 4, the 2 Cu protein lacks this band while it is evident in the spectrum of the $4 \mathrm{Cu}^{2+}$ derivative. Notably, concentrated solutions of $2 \mathrm{Cu}^{2+}$ derivative are cerulean blue as reported earlier [7] while native and $4 \mathrm{Cu}^{2+}$ proteins have a definite green color. The visually observed color differences are apparently due to the presence or absence of the $450 \mathrm{~nm}$ band. Similarly, it was shown [7] that occupation of the $\mathrm{Zn}^{2+}$ binding site was necessary for development of the characteristic EPR spectrum. Recently, Beem et al. [28] have shown that $\mathrm{Cd}^{2+}$ and $\mathrm{Hg}^{2+}$ will bind to the $\mathrm{Zn}$ site with the appearance of the native EPR spectrum and of the $450 \mathrm{~nm}$ band in the optical spectrum. While it is possible that this absorption is due to a charge transfer transition from the imidazolium anion bridging ligand to $\mathrm{Cu}^{2+}$ its low efficiency would suggest that it is primarily a d-d transition.

The oxidation-reduction properties of $4 \mathrm{Cu}^{2+}$ protein, while not studied in detail demonstrate the ability of the binuclear complex to act as a one-electron acceptor near the potential of the ferri/ferrocyanide couple. Hence, one of the $\mathrm{Cu}^{2+}$ ions is either unreactive toward ferrocyanide or the introduction of the second electron requires a stronger reducing agent. This behavior contrasts with the $\mathrm{Cu}^{2+}-\mathrm{Cu}^{2+}$ pairs in laccase [29] and tyrosinase [30] which act as two-electron redox centers. The different chemical properties of the two types of $\mathrm{Cu}^{2+}$ of $4 \mathrm{Cu}$ dismutase are also emphasized by their reactivity toward bathocupreine sulfonate. The rapidity with which half the $\mathrm{Cu}^{+}$is removed from $4 \mathrm{Cu}^{+}$protein suggests that one of the $\mathrm{Cu}$ binding sites is readily accessible to the chelating agent. If the assertion that $2 \mathrm{Cu}^{2+}$ dismutase represents the derivative in which the $\mathrm{Cu}$ site is occupied and the $\mathrm{Zn}$ site is unoccupied, then it can be concluded that the $\mathrm{Zn}$ Site, is accessible to a molecule the size of bathocupreine sulfonate and it has a comparatively low affinity for $\mathrm{Cu}^{+}$.

The apparent rhombicity of the EPR spectrum observed from the half-reduced $4 \mathrm{Cu}$ derivative suggests $\mathrm{Cu}^{2+}$ binding in a highly distorted ligand field. The unusually low hyperfine coupling constant, $A_{\|}, \approx 100 \mathrm{G}$, has been observed in a number of complexes of $\mathrm{Cu}^{2+}$ having a ligand field distorted away from the normal tetragonal field toward a tetrahedral arrangement of ligands [31], and while this is consistent with the X-ray deductions concerning the structure of the $\mathrm{Zn}$ site [14] care must be taken in deducing structural information from the value of this parameter [31, 32].

The EPR spectrum of the $4 \mathrm{Cu}^{2+}$ derivative clearly arises from an excited triplet state which is $\approx 52 \mathrm{~cm}^{-1}(=-2 \mathrm{~J})$ above a ground state singlet. Unfortunately, the magnetic properties of imidazolato-bridged $\mathrm{Cu}^{2+}$ systems have not been reported on making a comparison of this coupling constant with a well-defined model substance impossible, and none of the binuclear $\mathrm{Cu}^{2+}$ complexes which have been investigated would seem to serve as a good model for the present system [33, 34]. Attempts are presently underway to compute the spectrum shown in Fig. 3 and more information on the magnetic properties of $4 \mathrm{Cu}^{2+}$ dismutase will be presented elsewhere*.

\footnotetext{
${ }^{\star}$ K. Scheppler, W. R. Dunham, R. H. Sands and J. A. Fee, manuscript in preparation.
} 


\section{ACKNOWLEDGMENT}

We thank Professor R. H. Sands for valuable discussion and for help with the low temperature EPR experiment. This work was supported by grants from the U.S.P.H.S. GM 18869 and GM 21519.

\section{REFERENCES}

1 McCord, J. M. and Fridovich, I. (1969) J. Biol. Chem. 244, 6049-6055

2 Klug-Roth, D., Fridovich, I. and Rabani, J. (1973) J. Am. Chem. Soc. 95, 2786-2790

3 Fielden, E. M., Roberts, P. B., Bray, R. C., Lowe, D. J., Mautner, G. N., Rotilio, G. and Calabrese, L. (1974) Biochem. J. 139, 49-60

4 Gaber, B. P., Brown, R. D., Koenig, S. H. and Fee, J. A. (1972) Biochim. Biophys. Acta 271, 1-5

5 Fee, J. A. and Gaber, B. P. (1972) J. Biol. Chem. 247, 60-65

6 Rotilio, G., Morpurgo, L., Giovagnoli, C., Calabrese, L. and Mondovi, B. (1972) Biochemistry 11, 2187-2192

7 Fee, J. A. (1973) Biochim. Biophys. Acta 295, 107-116

8 Forman, H. J., Evans, H. J., Hill, R. L. and Fridovich, I. (1973) Biochemistry 12, 823-827

9 Fee, J. A. and DiCorleto, P. E. (1973) Biochemistry 12, 4893-4899

10 Carrico, R. J. and Deutsch, H. F. (1969) J. Biol. Chem. 245, 723-727

11 Fee, J. A. (1973) J. Biol. Chem. 248, 4229-4234

12 Rotilio, G., Calabrese, L., Mondovi, B. and Blumberg, W. E. (1974) J. Biol. Chem. 249, 3157-3160

13 Moss, T. H. and Fee, J. A., manuscript in preparation

14 Richardson, J. S., Thomas, K. A., Reubin, B. H. and Richardson, D. C. (1975) Proc. Natl. Acad. Sci. U.S., $72,1349-1353$

15 Diehl, H. and Smith, G. F. (1972) The Copper Reagents: Cuproine, Neocuproine, Bathocuproine, The G. F. Smith Chemical Co., 867 McKinley Ave., Columbus, Oh., p. 33

16 Hansen, R. E., Kalal, T. T. and Beinert, H. (1967) Anal. Biochem. 20, 40-45

17 Boas, J. F., Dunhill, R. H., Pilbrow, J. R., Srivistava, R. C. and Smith, T. D. (1969) J. Chem. Soc. Ser. A, 94-108

18 Sjoberg, S. (1971) Acta Chem. Scand. 25, 2149-2167

19 Ivarsson, G., Lundberg, B. K. S. and Ingri, N. (1972) Acta Chem. Scand. 26, 3005-3020

20 Lundberg, B. K. S. (1972) Acta Chem. Scand. 26, 3902-3912

21 Martin, R. B. (1974) Proc. Natl. Acad. Sci. U.S. 71, 4346-4347

22 Fee, J. A., Natter, R. and Baker, G. S. T. (1973) Biochim. Biophys. Acta 295, 96-106

23 Fee, J. A. (1973) Biochim. Biophys. Acta 295, 87-95

24 Fee, J. A. and Phillips, W. D., manuscript in preparation

25 Joester, K.-E., Jung, G., Weber, U. and Weser, U. (1972) FEBS Lett. 25, 25-27

26 Klug, D., Rabani, J. and Fridovich, I. (1972) J. Biol. Chem. 247, 4839-4842

27 Fridovich, I. (1974) Adv. Enzymol. 41, 35-97

28 Beem, K. M., Rich, W. E. and Rajagopalan, K. V. (1974) J. Biol. Chem. 249, 7298-7305

29 Fee, J. A., Malkin, R., Malmström, B. G. and Vänngård, T. (1969) J. Biol. Chem. 244, 4200-4207

30 Makino, N., McMahill, P., Mason, H. S. and Moss, T. H. (1974) J. Biol. Chem. 249, 6062-6066

31 Vänngård, T. (1972) Biological Applications of Electron Spin Resonances (Swartz, H. M., Bolton, J. R. and Borg, D. C., eds), pp. 411-447, Wiley-Interscience, New York

32 Peisach, J. and Blumberg, W. E. (1974) Arch. Biochem. Biophys. 165, 691-708

33 Ginsberg, A. P. (1971) Inorg. Chim. Acta Rev. 5, 545

34 Hodgson, D. J. (1975) Prog. Inorg. Chem. 19, 173-241 